\title{
Suburbanization as a problem of rural development
}

\author{
Żanna Stręk, ${ }^{*}$, Pawet Postek, Angelika Sobczak, Paulina Rybaczek \\ University of Life Sciences in Lublin, Department of Environmental Engineering and Geodesy, Leszczyńskiego 7 20-069 \\ Lublin, Poland; zanna.krol@up.lublin.pl
}

\begin{abstract}
Polish agriculture is now facing many problems. One of them is the fragmentation of land. This phenomenon is rooted in history. Farmers willing to distribute their assets among their children gave a certain part of the farm to each of them. Due to their intention to split the assets fairly between the heirs, the fragmentation of land increased. The arduousness of this phenomenon is manifested in the fact that plots that are too small or too narrow and their irregular shape make running profitable agricultural activity difficult. Another negative factor affecting the spatial arrangement of rural areas is the process of suburbanization. During suburbanization specific links are formed between the city and rural areas such as the flow of people, goods or capital. They play an important role in transforming those areas, and in particular in determining the method of management of such areas and the location of respective types of activity. Suburbanization leads to a decrease in the population density in city centres and an increase in the suburbs. The emigration of the indigenous city people to the suburbs grew in popularity. The effect of the process is a growing fragmentation of plots in order to separate building plots that are smaller and smaller. In many cases the plots used for agricultural purposes but in local spatial development plans destined for housing development are split into multiple smaller plots and with time they are turned into suburban single-family housing estates. The influx of urban communities and the related expansion of building development in rural areas lead to the loss of rural identity. This is how the agricultural nature of rural areas where farms withdraw from agricultural activity changes.
\end{abstract}

This article aims at exploring the selected spatial factors such as the analysis of use and fragmentation of land owned by private farmers, as well as the analysis of the suburbanization process in the villages within the commune of Konopnica in the Lublin county, Lublin voivodeship. The surveys were based on a cartographic and descriptive method. The method comprised a detailed survey of the spatial structure of selected villages within the commune of Konopnica based on a cadastral map, the index of plots and a reconnaissance. Information about the area of each plot and information about the registration unit was used as input data for a detailed analysis of the fragmentation of private plots in five area ranges, an analysis of the use of land, and a detailed analysis of changes in the size of farms in 2012-2017. The results of studies will make it possible to determine the direction and scope of changes in the fragmentation of land in the villages situated within the analysed commune.

\section{Introduction}

Polish agriculture is now facing many problems. One of them is the fragmentation of land. This phenomenon is rooted in history. Rural areas in Poland were traditionally used for agricultural purposes [1]. Farmers willing to distribute their assets among their children gave a certain part of the farm to each of them. Due to their intention to split the assets fairly between the heirs, the fragmentation of land increased. The arduousness of this phenomenon was manifested in the fact that plots that were very narrow or had an irregular shape were obstacles to profitable agricultural activity, as shown by the studies [2-7]. Due to the small area of a farm, some people treat it as residential quarters only [8]. In addition, the emigration of the indigenous city people to the suburbs grew in popularity. A common living model was oriented at building a career in order to live in a rural area in the future while working in the city. This process is called suburbanization and it is a spatial development of the city outside its administrative limits. The preferred settlement locations are situated from 6 to $20 \mathrm{~km}$ away from cities. However, the commuting time is a more and more significant criterion and preferably it should be from 15 to 20 minutes [9]. The process of suburbanization is noticeable both in Poland [10] and throughout the world, e.g. in the USA [11] or Sydney [12]. The influx of urban communities and the related expansion of building development in rural areas lead to the loss of rural identity. This is how the agricultural nature of rural areas where

\footnotetext{
Corresponding author: zanna.krol@up.lublin.pl
} 


\section{Environmental Engineering, Photogrammetry, Geoinformatics - Modern Technologies and Development Perspectives}

farms withdraw from agricultural activity changes. However, growing suburbanization also has a positive effect on rural areas, for instance, through the proceeds from taxes. As shown below, the preferred building plots have an area of up to 0.10 ha. According to the Act [13], when the plots are split, betterment levies can be charged as income for local commune offices [14-16].

According to the data of the Central Statistical Office [17], the number of free farms in June 2016 in Poland was 1410.7 thousand. 99.7\% of them (1406.6 thousand) were private farms that owned $91.4 \%$ of all agricultural land. Rural areas are seen as one of the most important elements of Polish social and economic reality and they constitute a complex problem to be solved in the process of national development [18]. After the accession of Poland to the European Union in 2004, Polish agriculture was offered chances of multifunctional and sustainable development. This is one of the main assumptions of the European Union's policy. Its main purpose is to improve the living and working conditions of farmers and their families. Looking at the development as a whole, the specific needs of small family farms, constituting an important element of the agriculture model and the basis for the discussed development, should be taken into account. The necessary social and economic changes should be based on the functions of a specific area. It is advisable that a spatial planning system is in place providing the basis for the development of rural areas. It is also very important that the local community is involved and full information is provided at the project preparation stage. This will result in an increased confidence of the community. Every form of multifunctional development should include legal procedures protecting the interests of private farmers [19, 20] The Rural Development Programme (RDP), financed from the funds of the European Union, plays a very important role in the process of development of present-day rural areas. The main objectives of RDP for the years 20142020 include improvement in the competitiveness of agriculture, sustainable management of natural resources and climate measures and sustainable territorial development of rural areas. The European Union also provides financing to land consolidation projects and post-consolidation spatial development projects [21]. These are measures that can have a positive effect on the spatial structure of rural areas. Land consolidation and exchange is an operation which can facilitate improvement of the spatial structure of rural areas. Such works make it possible to properly organize farmsteads at the same time preserving the natural environment. It provides adequate conditions for sustainable multifunctional development of rural areas by limiting the harmful effect of intensive agriculture on the natural environment and leads to improvement in the living and working conditions for the inhabitants of rural areas [22].

This article aims to explore selected spatial factors such as the analysis of use and fragmentation of land owned by private farmers, and their effect on the process of suburbanization in the villages within the commune of Konopnica in the Lublin county, Lublin voivodeship. The results of the studies will make it possible to determine the direction and scope of changes regarding agricultural land in the villages situated within the analysed commune.

\section{Materials and methods}

The object of the study is the commune of Konopnica (Fig. 1) situated in the close neighbourhood of the city of Lublin in the Lublin county, that is, the capital city of the Lublin voivodeship and the largest city in eastern Poland. The commune consists of 20 villages covering an area of $9194.5 \mathrm{~km}^{2}$. The total number of plots is 21199, where 8489 are plots owned by private farmers. The average area of a plot from group 7 is 0.51 ha. Agricultural land occupies 8119.02 ha, that is, about $87.3 \%$ of all land in use in the commune. Half of the farms in the commune of Konopnica are self-sufficient farmsteads, and $25 \%$ of all farms do not run economic activity. Other farms offer directmarket production. However, good soil conditions such as: high soil quality, convenient climate, terrain relief and good water regime foster the development of agriculture. The commune is intersected by transport routes of national and regional significance such as national road no. 19 and a western section of the Lublin ring road as well as railway tracks [23]. A well-developed transport infrastructure makes this commune an attractive housing area and is a evidence of its strong links to the city of Lublin. 
Environmental Engineering, Photogrammetry, Geoinformatics - Modern Technologies and Development Perspectives

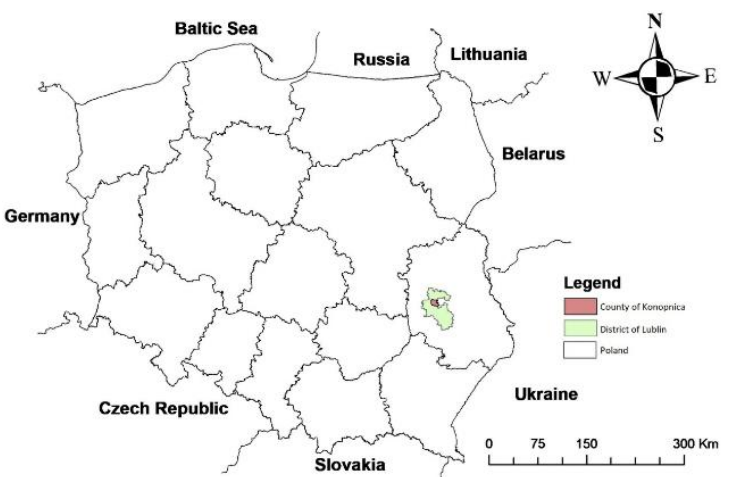

Fig. 1. Map of location of the studied commune

The surveys were based on a cartographic and descriptive method. The method comprised a detailed survey of the spatial structure of selected villages within the commune of Konopnica based on a cadastral map, the index of plots and a reconnaissance. Information about the area of each plot and information about the registration unit was used as input data for a detailed analysis of the fragmentation of private plots in five area ranges, an analysis of the use of land, and a detailed analysis of changes in the size of farms in 20122017. The place of residence of plot owners was established on the basis of their postal codes. The influence of the city of Lublin on the commune of Konopnica was investigated by analysing several factors: the changing surface area of residential grounds and all land in the group of private persons who own and who do not own farms, the location and concentration of plots owned by the residents of Lublin as well as the location and concentration of plots with a surface area up to 10 ares as the land fragmentation index.

\section{Result and discussion}

The use of land means the utilization of land according to its purpose. The total area of a farm is inclusive of all land forming part of the farm, that is, all land used for agricultural purposes (cropland, orchards, meadows and pastures), land used for non-agricultural purposes: forests, courtyards, land under buildings or land for building development, decorative gardens etc. Land in use is a continuous part of the earth surface that is used in a uniform manner. For the purposes of the present-day register of land and buildings, seven groups of usable land were distinguished and described with respect to land cover and land use [24].

Table 1. Structure of land in use in the Konopnica commune

\begin{tabular}{|c|c|c|c|}
\hline No. & Type of land in use & Area in ha & \% \\
\hline 1 & Cropland & 6724.03 & 72.3 \\
\hline 2 & Orchards & 503.34 & 5.4 \\
\hline 3 & Permanent meadows & 126.8 & 1.4 \\
\hline 4 & Permanent pastures & 136.1 & 1.5 \\
\hline 5 & $\begin{array}{c}\text { Built-up agricultural } \\
\text { land }\end{array}$ & 622.4 & 6.7 \\
\hline 6 & Wasteland & 6.35 & 0.1 \\
\hline \multicolumn{2}{|c|}{ Total land in use } & 8119.02 & 87.3 \\
\hline 7 & Forests and forestland & 474.18 & 5.1 \\
\hline 8 & $\begin{array}{c}\text { Land with tree stands } \\
\text { and shrubs }\end{array}$ & 0 & 0.0 \\
\hline Total forestland in use & 474.18 & 5.1 \\
\hline 9 & Ditches & 6.8 & 0.1 \\
\hline 10 & Pond bottoms & 9.92 & 0.1 \\
\hline 11 & Built-up grounds & 211.88 & 2.3 \\
\hline 12 & $\begin{array}{c}\text { Urbanized grounds } \\
\text { without buildings }\end{array}$ & 0.77 & 0.0 \\
\hline 13 & Transport grounds & 367.6 & 4.0 \\
\hline 14 & $\begin{array}{c}\text { Bottoms of surface } \\
\text { water courses }\end{array}$ & 2.74 & 0.0 \\
\hline 15 & Other grounds & 108.99 & 1.2 \\
\hline \multicolumn{2}{|c|}{ Total } & 9301.9 & 100.0 \\
\hline
\end{tabular}

The structure of land use in the commune of Konopnica, according to Table 1 , is dominated by land in use, which accounts for as much as $87 \%$ of the total area of the commune and occupies an area of 8119.02 ha. Agricultural land is dominated by cropland with an area of 6724.03 (72.3\%). Grassland accounts only for $2.9 \%$ of the area of the analysed commune, where: permanent pastures are 136.10 ha $(1.5 \%)$ and permanent meadows are 126.8 ha $(1.4 \%)$. It should be noted that the forest cover is scarce and is 474.18 ha $(5.1 \%)$.

The spatial arrangement of private land, developed throughout the course of history in the villages of southern and southeastern Poland, is characterised by the presence of farms with a small surface area. Their land is fragmented and their constituent plots are dispersed. The fragmentation of land is visible in Poland $[25,26]$ but also, among other countries, in Mexico [27], India [28], Central Europe [29], China [30], Cyprus [31], Czech Republic [32], Slovakia [33] and Croatia [34]. The studies showed that the fragmentation of land is also present in the commune of Konopnica. Another problem is the fact that many owners of farms in the above-mentioned commune are not the residents of the commune of Konopnica. The structure of fragmentation of plots in the study area was analysed only for plots owned by private 
Environmental Engineering, Photogrammetry, Geoinformatics - Modern Technologies and Development Perspectives

persons within groups according to size, which is illustrated in Table 2.

Table 2. Structure of fragmentation of private plots in the Konopnica commune

\begin{tabular}{|c|c|c|}
\hline $\begin{array}{c}\text { Area ranges } \\
\text { [ha] }\end{array}$ & $\begin{array}{c}\text { Number } \\
\text { of plots } \\
{[\%]}\end{array}$ & $\begin{array}{c}\text { Surface area of } \\
\text { plots [\%] }\end{array}$ \\
\hline$<0.10$ & 29.3 & 3.1 \\
\hline $0.11-0.30$ & 31.2 & 13.5 \\
\hline $0.31-0.60$ & 20.1 & 19.7 \\
\hline $0.61-1.00$ & 8.8 & 15.9 \\
\hline$>1.01$ & 10.6 & 47.8 \\
\hline Total & 100.0 & 100.0 \\
\hline
\end{tabular}

As shown by Table 2 and by detailed analyses, private persons own 5654.01 ha of land, which corresponds to $60.8 \%$ of the total study area. This area is split into 8489 plots with an average surface area of 0.51 ha. An average surface area of a plot in the analysed commune can be used for a general evaluation of their occurrence in the villages. On the other hand, it does not reflect their different sizes in the respective villages of the analysed commune. Therefore, the fragmentation of plots in the villages of the commune of Konopnica was analysed in detail assuming 5 area ranges. It can be concluded that in the analysed commune the highest number of plots falls within the area range from 0.11 to 0.30 ha and accounts for as much as $31.2 \%$. Another area range where the number of plots is high is up to 0.10 ha $(29.3 \%)$; these are mainly plots with residential buildings separated in order to expand single-family housing development in respective villages. It is worth noting that plots with a larger area are not so numerous - the range from 0.31 to 0.60 ha accounts for only $8.8 \%$ of the total number of private plots in the commune, and plots with a surface area exceeding 1.01 ha make up only $10.6 \%$.

Apart from the fragmentation of plots, the commune of Konopnica shows significant deficiency in the external patchwork of private land. With respect to suburbanization issues, the survey covered the identification of plots whose owners live in the nearby voivodeship city of Lublin. The survey analysed in detail the ownership of plots with an area up to 0.10 ha due to the fact that these are mostly plots with residential buildings or plots designed for housing development. During suburbanization specific links are formed between the city and rural areas such as the flow of people, goods and capital. City residents most eagerly build their houses on small plots. The links between the urban and the rural areas play an important role in transforming those areas, and in particular, in determining the method of management of such areas and the location of respective types of activity. Consequently, suburbanization has a huge influence on the spatial development of rural areas [35]. Suburbanization leads to a decrease in the population density in city centres and an increase in the suburbs.

Information in Table 3 indicates that as many as $44 \%$ of owners of plots with a surface area up to 10 ares are residents of Lublin. Thus, residents who arrived from Lublin have a big influence on the spatial structure of the commune of Konopnica.

Table 3. Owners of plots up to 0.10 ha in the Konopnica commune

\begin{tabular}{|c|c|}
\hline & $\begin{array}{c}\text { Share of Lublin residents in } \\
\text { the ownership of plots up to } \\
\mathbf{0 . 1 0} \text { ha [\%] }\end{array}$ \\
\hline $\begin{array}{c}\text { Residents of } \\
\text { Lublin }\end{array}$ & 44.48 \\
\hline Other & 55.52 \\
\hline
\end{tabular}

As shown in Figure 3, the highest percentage of plot owners from Lublin is observed in villages bordering on the city of Lublin, i.e. Zemborzyce Wojciechowskie (87\%), Zemborzyce Dolne (87\%), Zemborzyce Tereszyńskie (84\%), Lipniak (79\%) and Szerokie (77\%). The further from the limits of Lublin, this percentage decreases, and is the lowest in the village of Pawlin (19\%).

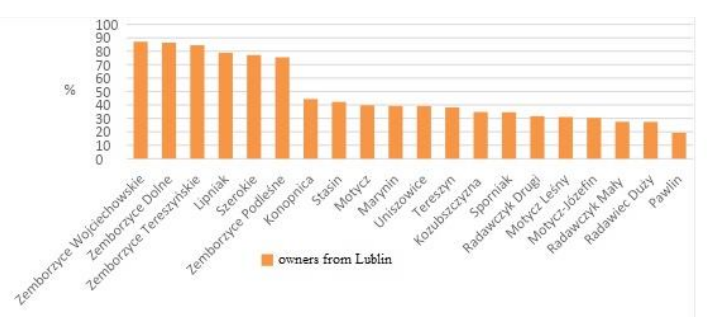

Fig. 3 Percentage of owners from Lublin in respective precincts of the commune of Konopnica

According to legal regulations applicable in the Integrated System of Management and Control, if the surface area of plots is below 0.10 ha, agricultural producers are not entitled to payments from the EU [13]. This is also 


\section{Environmental Engineering, Photogrammetry, Geoinformatics - Modern Technologies and Development Perspectives}

why people arriving from cities buy such plots eagerly. The percentage of plots with a surface area up to 0.10 ha was analysed, which is presented in Figure 4.

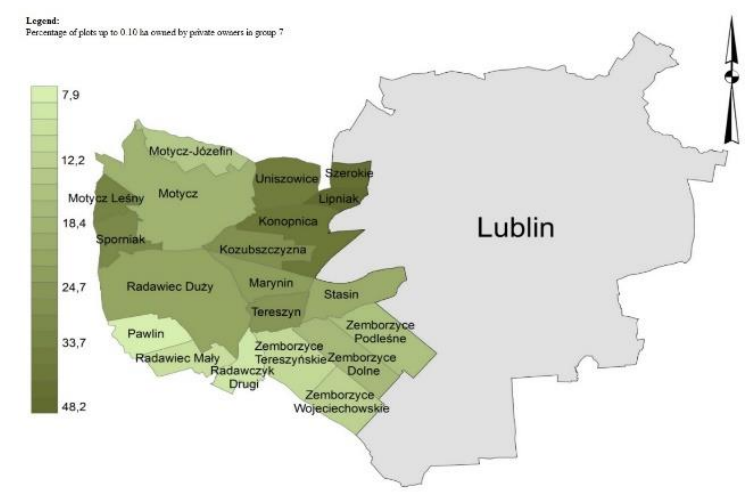

Fig. 4 Percentage of plots up to 0.10 ha owned by private owners

The map illustrates the percentage of plots up to 10 a owned by private owners in respective villages The largest concentration of such plots is found in the northeastern part of the commune, in the close neighbourhood of Lublin. The largest fragmentation is observed in Szerokie, Lipniak, Uniszowice and Konopnica. The northern part of the commune, despite its proximity to the city, still remains an agricultural area. In Zemborzyce Wojciechowskie and in Pawlin, agricultural land accounts for as much as $98 \%$ of all land. In addition, residential grounds account for about $0.4 \%$ of the area. This may be due to a larger distance from the city centre and at the same time decreased attractiveness of the area to potential new residents. On the other hand, as regards Szerokie and Lipniak, according to the surface area of residential grounds they rank first in the commune. As much as $10 \%$ of land in use is residential grounds. Information from the database of the land and buildings register was used as input data for a detailed analysis of the surface area of private land. According to the Regulation [2001], private land is split into two subgroups: 7.1 and 7.2. The first of them defines the area forming part of the farm, while the other defines land not forming part of farms, i.e. the area per owner does not exceed 1.00 ha. Detailed analyses for the commune of Konopnica in years 2012-2017 were carried out based on the land registers, which is presented in Figure 5.

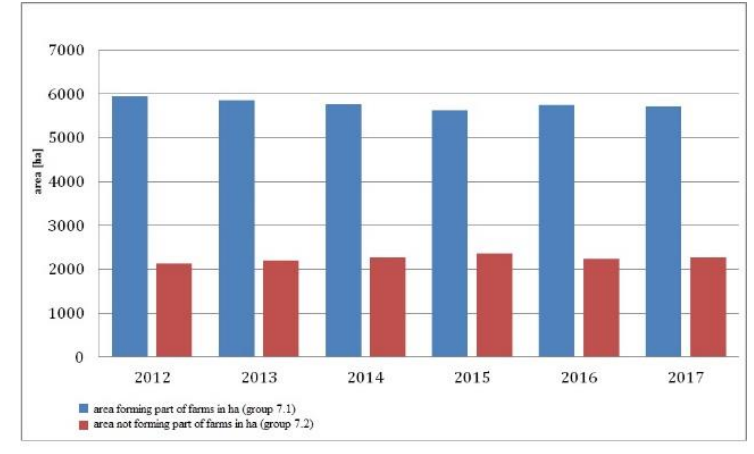

Fig. 5 The area of agricultural land in register subgroups 7.1 and 7.2

The surface area of land forming part of farms, i.e. owned by owners of plots from subgroup 7.1, decreased by 241 ha over 6 years from 2012, which accounts for $2.6 \%$ of the total area of the commune. On the other hand, the surface area of land owned by private persons who do not own a farm increased by $138 \mathrm{ha}$, which corresponds to 1.5 $\%$ of the area of the commune of Konopnica. This is further evidence of the growing fragmentation of plots in the commune and of the fact that they are acquired by persons who do not own farms, that is, in most cases, residents arriving from cities. To support the above-mentioned statement, the changes in the surface area of built-up land in 20122017 were analysed. The results are presented in Figure 6.

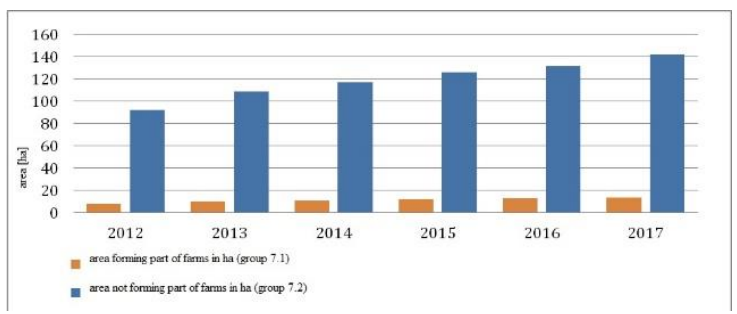

Fig. 6 Surface area of residential grounds in groups 7.1 and 7.2

The chart (Fig. 6) shows a significant increase in the surface area of built-up land in both groups. In group 7.2 (land not forming part of farms) from 2012 the surface area of such land increased by 50.0 hectares. On the other hand, in group 7.1 (farms) the surface area increased by 6 hectares. The considerable difference in the built-up area between groups 7.1 and 7.2 is most likely due to the fact that residential grounds also form part of built-up agricultural land. It means that these are all farm buildings and residential buildings within the 
Environmental Engineering, Photogrammetry, Geoinformatics - Modern Technologies and Development Perspectives

specific plot. In turn, residential grounds were defined as land not used for the purposes of agricultural and forest production.

To sum up, in 2012-2017 a significant increase can be observed in the surface area of residential grounds and of the land owned by persons who do not own farms. This testifies to a growing fragmentation of plots in the analysed commune and an increasing suburbanization which affects the building development of rural areas in the commune of Konopnica.

Another argument in support of fragmentation of land in the analysed commune is the ladder-type patchwork occurring in, among other villages, Lipniak and Szerokie, which is illustrated in Fig. 7 and Fig. 8 The ladder-type patchwork is mainly seen in the eastern parts of the analysed villages. This is a phenomenon characteristic for large fragmentation of land and dense housing development.

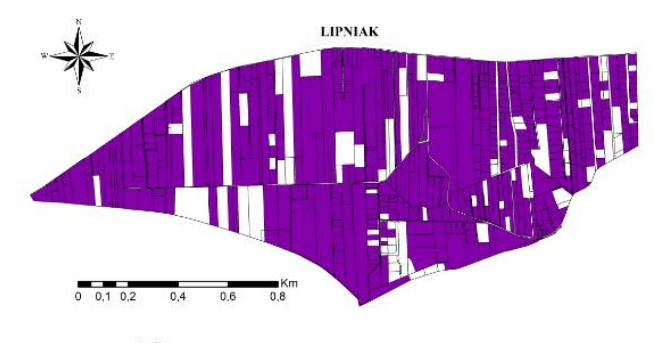

Fig. 6 Patchwork of plots in the village of Lipniak

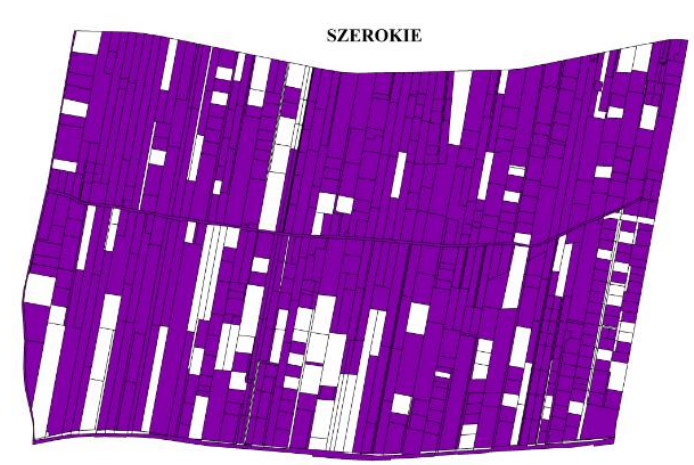

Fig. 7 Patchwork of plots in the village of Szerokie

The ownership structure was also analysed. Plots in Lipniak and Szerokie are mostly owned by residents of Lublin, which is marked in purple (Fig. 6, Fig. 7). This is the land owned by the so-called out-of-village non-resident owners, that is, owners of plots situated in the analysed village or commune but living outside this village. Other plots marked in white are owned by residents of the commune of Konopnica. Both villages border on the city of
Lublin, and the concentration of building development is the largest on the side next to the city. According to analyses carried out in selected villages of the commune of Konopnica, the largest share in the structure of ownership is allocated to private persons. The area of private land is $5794 \mathrm{ha}$, which corresponds to $62.29 \%$ of the total area of the analysed commune.

\section{Conlusion}

Every year in Poland thousands of people change their place of residence. They are mostly professionally active people who leave urban areas and settle down in the nearby villages, preferably situated close to their administrative limits. This phenomenon is called suburbanization, that is, the "spilling" of the city. New residents have a very big influence on the spatial development of rural areas. The housing development of such areas increases the fragmentation of land. Most eagerly bought plots are small plots with an area, for example, up to $0.10 \mathrm{ha}$. This fact also contributes to decreasing the area of cropland. In addition, the number of plots owned by out-of-village non-resident owners, that is, owners of plots in the specific village who do not live in such a village, increases. It can be supposed that this is noted when city people buy a plot in the rural area in connection with house building plans. When the house is completed, the people are practically residents of the specific village but only after they officially register as residents they cease to be out-of-village nonresident owners.

Such situations were also noted in the analysed area. The most popular area to potentially new residents of the commune of Konopnica is its northern and eastern part located at the closest distance to the centre of the city of Lublin. These are the villages: Lipniak, Szerokie, Konopnica and Uniszowice. The largest fragmentation of plots is observed in areas with a large share of residential grounds mostly owned by residents of Lublin. The survey showed an increase in building development with a simultaneous decrease in the area of agricultural land, which points to progressing suburbanization. However, despite this process, some villages still maintain their agricultural character.

An answer should be provided to the question whether progressing suburbanization is a problem of rural areas. Certainly, the "spilling" of the city is unfortunately inevitable. In the years after the war 


\section{Environmental Engineering, Photogrammetry, Geoinformatics - Modern Technologies and} Development Perspectives

many people "fled" from rural areas to urban areas, whereas recently in Poland a reverse trend has been observed. As a matter of fact, building houses in rural areas or at the outskirts of the city has become trendy. It ought to be remembered that new residents have a very large influence both on the landscape and on the environment of rural areas. Instead of crop fields, the landscape of the commune of Konopnica, and mainly of the villages Lipniak and Szerokie, is dominated by singlefamily houses with characteristic plants and infrastructure, that is, other building structures. However, it must not be forgotten that new residents also have a positive impact on the villages in which they live. They guarantee proceeds from local taxes, are often local activists, run business activity in the area and their children attend local schools.

To sum up, suburbanization has both positive and negative aspects. It is the residents, both indigenous and migrant, who determine the direction of development for Polish rural areas.

\section{Acknowledgements}

Publication is funded by the Polish National Agency for Academic Exchange under the International Academic Partnerships Programme from the project „Organization of the 9th International Scientific and Technical Conference entitled Environmental Engineering, Photogrammetry, Geoinformatics - Modern Technologies and Development Perspectives".

\section{References}

1. Źróbek-Różańska A., Zysk E.. Real estate as a subject of spatial conflict among central and local authorities. Real Estate Management and Valuation. 23 (2): 88-98. (2015)

2. Leń P., Noga K. Prioritization of Land Consolidation Interventions in the Villages of Central Poland. Journal of Ecological Engineering, Volume 19, Issue 2, March 2018, pp. 248-256.(2018)

3. Król, Ż.; Leń, P. Individual plot patchwork determination of the urgency in realization consolidation and exchange of land. Infrastruct. Ecol. Rural Areas 2016, 311322 (2016)

4. Leń P., Mika M. Determination of the urgency of undertaking land consolidation works in the villages of the Sławno municipality. Journal of Ecological Engineering. Volume 17, Issue 4, Sept. 2016, pp. 163-169 DOI: 10.12911/22998993/64827. (2016)
5. Leń, P. The size of the external patchwork of fields as an indicator of the need for land consolidation and exchange in the villages of the commune of Drzewica. $J$. Water Land Dev. 33, 99-106, doi:10.1515/jwld-2017-0024. (2017)

6. Strek Z. Engineering for rural development analysis of demand for land consolidation in Milejów commune, Łęczna district. ENGINEERING FOR RURAL DEVELOPMENT, Jelgava, 24.26.05.2017, pp. 593-599, DOI: 10.22616/ERDev2017.16.N119. (2017)

7. Wójcik-Leń J., Stręk Ż., Proposal for land consolidation project solutions for selected problem areas. World Multidisciplinary Earth Sciences Symposium (WMESS 2017). Earth and Environmental Science 95 (2017) 032016, September 11-15, 2017, Prague, DOI :10.1088/17551315/95/3/032016. (2017)

8. Sobolewska-Mikulska, K. (Ed.) Contemporary Consolidation of Land in Shaping the Limits of Agricultural Production Space; Publishing House of the Technical University of Warsaw: Warsaw, Poland, (2009)

9. Źróbek-Różańska A., Źróbek S. How city's biggest employers shape spatial development of the residential areas evidence from Olsztyn, Poland. Environmental Engineering, pp. 1-8, DOI: 10.3846/enviro.2017.130. (2017)

10. Źróbek-Różańska A., Źróbek S., Źróbek R. Urban Sprawl and the Problems of Changes of Land Use on the Fringe Areas of Towns. International Conference on Environmental Engineering. (2014)

11. Coisnon T., Oueslati W., Salanié J., Urban sprawl occurrence under spatially varying agricultural amenities, Regional Science and Urban Economics, No. 44, pp. 38-49. (2014)

12. Chen G., Hadjikakou M. Wiedmann T., Shi L., Global warming impact of suburbanization: The case of Sydney, Journal of Cleaner Production, 172 (2018), pp. 287-301. (2018)

13. Act of 26 January 2007 on direct payments (Dz. U. (JL) of 2007 No. 35 item 217)

14. Dawid L., Analiza opłat adiacenckich na przyktadzie gminy Stupsk (Analysis of adjacent fees on the example of the Stupsk commune), REAL ESTATE MANAGEMENT AND VALUATION, Vol.: 20 Booklet: 4, pp. 77-88, LIST B, item 1456, scoring (2012)

15. Dawid L., Ocena naliczania optat adiacenckich na przykładzie gminy wiejskiej Krokowa (Assessmen of adiacent 
Environmental Engineering, Photogrammetry, Geoinformatics - Modern Technologies and Development Perspectives

fees calculation on the example of Krakow rural commune), Infrastructure and Ecology of Rural Areas, Volume: II/3, pp. 143-153, LIST B, item 805, scoring (2013)

16. Dawid L., Wzrost wartości nieruchomości na skutek podziałów nieruchomości $i$ budowy urzadzen infrastruktury technicznej na przykladzie gminy Mielno (Increase in the value of real estate as a result of divisions of real estate and construction of technical infrastructure devices on the example of the Mielno commune), MOTROL Motoryzacja $i$ Energetyka Rolnictwa, Volume: 16 Booklet: 1, pp. 19-24, LIST B, ITEM 1397, SCORING (2014)

17. GUS 2016: Główny Urząd Statystyczny. Charakterystyka gospodarstw rolnych $w$ 2016 r. (Central Statistical Office. Characteristics of farms in 2016), Warszawa. Accessed on: 29.07.2019 (2016)

18. Sobolewska-Mikulska K., Wójcik-Leń J., 2018. Obszary problemowe rolnictwa $w$ Polsce wybrane aspekty realizacji scaleń gruntów (Problem areas of agriculture in Poland selected aspects of land consolidation). Oficyna Wydawnicza Politechniki Warszawskiej. Warszawa (2018). In Polish

19. Przegon W. Geodezja rolna i architektura krajobrazu w ksztaltowaniu przestrzeni rurystycznej. Teoria, badania, aplikacje. Ed. University of Agriculture in Kraków. (2016)

20. Sobolewska-Mikulska K. Kierunki modernizacji struktur przestrzennych obszarów wiejskich po wstapieniu Polski do Unii Europejskiej (Direction of modernization of spatial structures of rural areas after Poland's accession to the European Union). Przegląd Geodezyjny. No. 76 pp. 11-14. (2004) In Polish

21. The Rural Development Program. Available online:

https://www.gov.pl/documents/912055/91 3531/Program_Rozwoju_Obszar\%C3\%B3 w_Wiejskich_na lata

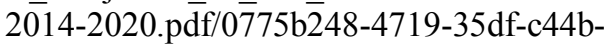
e81ffe4e977a (accessed on 4 March 2019).

22. Wójcik G., Leń P., Spatial development of agricultural land division throughout the ages in villages of the Opoczno County. Geomatics And Environmental EngineeringVol. 9/3. (2015)

23. Strategia rozwoju gminy Konopnica na lata 2016-2022 (Development strategy of the Konopnica commune for 2016-2022) In Polish
24. Regulation of the Minister of Regional Development and Construction of 29 March 2001 concerning land and buildings register (Dz. U. (Journal of Laws) of 2016, item 1034).

25. Strek Z. Engineering for rural development analysis of demand for land consolidation in Milejów commune, Łęczna district. ENGINEERING FOR RURAL DEVELOPMENT, Jelgava, 24.26.05.2017, pp. 593-599, DOI: 10.22616/ERDev2017.16.N119. (2017)

26. Wójcik-Leń J., Stręk Ż., Proposal for land consolidation project solutions for selected problem areas. World Multidisciplinary Earth Sciences Symposium (WMESS 2017). Earth and Environmental Science 95 (2017) 032016 DOI :10.1088/17551315/95/3/032016. (2017)

27. Bentley J. W. Economic and ecological approaches to land fragmentation: in defense of a much-maligned phenomenon. Annual Review of Anthropology 16, s.3167. (1987)

28. Manjunatha A. V., Anik A. R., Speelman S., Nuppenau E. A.. Impact of land fragmentation, farm size, land ownership and crop diversity on profit and efficiency of irrigated farms in India. Land Use Policy, 31, s. 397-405. https://doi.org/10.1016/j.landusepol.2012.0 8.005. (2013)

29. Pašakarnis G., Maliene V. Towards sustainable rural development in Central and Eastern Europe: Applying land consolidation. Land Use Policy, 27(2), s. 545-549.

https://doi.org/10.1016/j.landusepol.2009.0 7.008. (2010)

30. Guo B., Jin X., Yang X., Guan X. Lin Y., Zhou Y. Determining the effects of land consolidation on the multifunctionlity of the cropland production system in China using a SPA-fuzzy assessment model. EuropeanJournal of Agronomy. 63 (2015), s. 12-26. (2015)

31. Demetriou D., Stillwell J., See L.. A new methodology for measuring land fragmentation. Computers, Environment and Urban Systems, 39. 71-80. (2013)

32. Sklenicka, P.; Janovska, V.; Salek, M.; Vlasak, J.; Molnarova, K. The Farmland Rental Paradox: Extreme land ownership fragmentation as a new form of land degradation. Land Use Policy 38, 587593.

33. Hudecova, L.; Geisse, R.; Gasincova, S.; Bajtala, M. Quantification of Land Fragmentation in Slovakia. Geod.(2014) 
Environmental Engineering, Photogrammetry, Geoinformatics - Modern Technologies and Development Perspectives

34. Tomic, H.; MastelicIvic, S.; Roić, M. Land Consolidation Suitability Ranking of Cadastral Municipalities: InformationBased Decision-Making Using MultiCriteria Analyses of Official Registers' Data. Int. J. Geo-Inform. 7, 87, doi:10.3390/ijgi7030087. (2018)

35. Harasimowicz A. Suburbanizacja a rola obszarów wiejskich otaczających miastoujęcie teoretyczne (Suburbanization and the role of rural areas surrounding the city - theoretical approach). Studia miejskie, 29 (2018) 